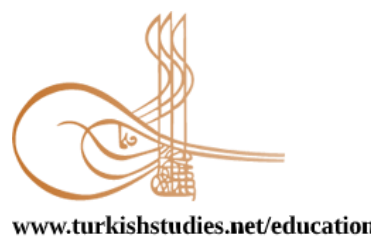

Turkish Studies - Educational Sciences

\title{
Sosyal Bilgiler Dersinde Öğrencilerin Öğrenme Stilleri ile Akademik Başarıları Arasındaki İlişsi
}

\author{
The Relationship Between Students 'Learning Styles and Academic Successes in Social Sciences
}

\author{
İrfan Arıkan* - Cengiz Taşkıran** - Süleyman Aslan ***
}

\begin{abstract}
The aim of this study, which was carried out in Diyarbakır province in the first semester of the 20192020 academic year, is to investigate the relationship between the academic achievement of the 5th, 6th and 7th grade students of the Secondary School and their learning styles, and to test whether students' learning styles differ according to their gender and class levels. Research is a study in the screening model, which is one of the quantitativ eresearch methods. The typical case sampling method was preferred from the intended sampling types in the study. $60.7 \%$ of the participants are female students, while $39.3 \%$ are male students. Of the 145 students participating in the research, 76 are 5th grade, 33 are 6th grade and 36 are 7 th grade students. The data obtained from the research was also analyzed in the SPSS 22 program. According to the findings obtained in the study, $66.9 \%$ of students have visual, $4.1 \%$ movement and $29 \%$ auditory based learning style. As a result of the research, there is no meaningful relationship between the students' mean scores of social studies term and their learning styles based on visual, movement and auditory. There is no significant difference between learning styles and gender. However, there is a significant difference between learning styles and grade levels. While movement-based and visual-based learning styles do not change according to grade levels, auditory-based learning styles change according to grade levels. According to the scores obtained from the scale, the auditory-based learning style levels of the sixth and seventh grade students are significantly higher than the fifth grades.
\end{abstract}

Structured Abstract: Today, modern research in education and new understandings in education have made great changes in terms of education and individual (Kolb, 1984). It was determined that students' assuming that they have equal experiences in the same classroom environment are different from each other. Forcing students

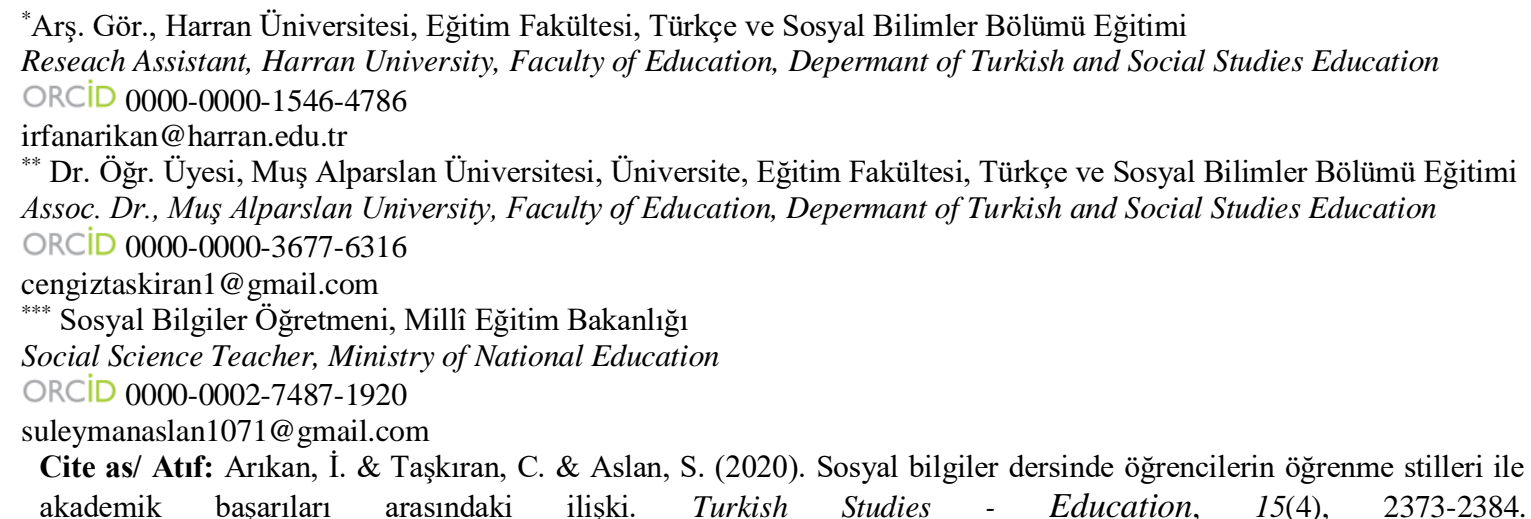
akademik başarıları arasındaki ilişki.
https://dx.doi.org/10.47423/TurkishStudies.43717

Received/Geliş: 20 May/Mayıs 2020

Accepted/Kabul: 27 August/Ağustos 2020

Copyright $($ INTAC LTD, Turkey 
whose individual differences to be ignored to learn with the same style of learning models in the same learning environment will be the biggest mistake of the education system.

In the social studies course, this is because it reveals how these learning style differences affect academic achievement as each student has individual differences in perception, processing, interpretation, and interpretation of information while learning and acquiring unique and unique information while learning or acquiring new and complex information. It is thought that the study will contribute to the related literature and it is aimed to increase the success of the students by considering the unique learning styles of the students during the planning and arrangement of the learning and teaching process.

The aim of this study is to investigate the relationship of academic achievement averages with learning styles and whether learning styles vary according to gender and class levels in the social studies course of the students who attend 5th,6th and 7th grade of secondary school. In this context, the answers to the following questions were sought in the research:

1. How the students' learning styles are distributed.

2. Is there a significant relationship between students' learning styles and academic achievements of the social studies course?

3. Do the learning styles of the students differ according to their gender?

4. Do the learning styles of the students differ according to their class levels?

\section{Method}

Research is a quantitative research in the screening model. Karasar'a (2016, p. 109) according to the screening model "is a research model that aims to detect a past or present situation as it exists."

\section{Sampling}

This research was conducted in two secondary schools in Diyarbakir during the first semester of the 2019 - 2020 academic year. The typical case sampling method was preferred from the intended sample types in the study. A total of 145 students, including 88 female students and 57 male students, participated in the study.

\section{Data Collection Tool}

The learning styles scale developed by student fact sheet and Sever (2008) was used in this research, which tested the relationship between students ' learning styles and academic achievement. Developed for sixth, seventh, and eighth grades and consisting of 17 items, this scale is 3 -factor, explaining $40.15 \%$ of the total variance. The Cronbach Alpha internal consistency coefficient of the scale is for each lower dimension. Calculated as 67. This study is also based on the scale's visual learning style cronbach Alpha internal consistency coefficient .63, movement-based learning style cronbach Alpha internal consistency coefficient .69 and aural-based learning style is the cronbach Alpha internal consistency coefficient. Calculated as 65.

\section{Analysis of the Data}

The data obtained from the research was also analyzed in the SPSS 22 program. A simple linear correlation test was conducted to test whether there was a significant relationship between the students ' social studies course end-of-term averages and learning styles. The t test was performed for unrelated samples to test whether there was a significant difference between the students ' learning styles and their gender status. A oneway variance analysis test was used to test whether there were any significant differences between grade levels and learning styles.

\section{Conclusion}

$66.9 \%$ of the students involved in the study had a visual, $4.1 \%$ movement and $29 \%$ auditory based learning style. According to these results, the majority of students have visual learning styles.

Final grade averages in social studies with learning styles of each child performed in order to test whether or not there was a significant relationship between the size of simple linear Pearson correlation test as a result of the students final grade averages in social studies with visual, motion, and visual based, there was a significant relationship between learning styles. 
The t-test results show that there is no statistically significant difference between movement-based, auditory-based and visual-based learning styles among male and female students for unrelated samples to test whether their learning styles change according to gender status.

As a result of the one-way analysis of variance (ANOVA) conducted to test whether the learning styles of the students participating in the research change according to their class levels, the movement-based and visual-based learning styles do not change significantly according to their class levels; Auditory-based learning styles differ statistically significantly according to grade levels. The effect size calculated as the result of the test was calculated as $(\eta 2=0.075)$. It is seen that the effect size obtained is at a medium level (Green \& Salkind, 2005, p.157). As a result of LSD multiple comparison test, it is seen that the significant difference is between the 5 th and 6 th and 7 th grades.

Keywords: Social Studies, Learning Style, Academic Achievement, Gender, Class Level

Öz: 2019- 2020 eğitim öğretim yılı birinci döneminde Diyarbakır ilinde gerçekleştirilen bu araştırmanın amacı Ortaokul beşinci, altıncı ve yedinci sınıf öğrencilerin sosyal bilgiler dersi akademik başarısı ile öğrenme stilleri arasındaki ilişkiyi araştırmak ve öğrencilerin öğrenme stillerinin cinsiyet durumlarına göre ve sınıf düzeylerine göre farklılaşıp farklılaşmadığını test etmektir. Araştırma nicel araştırma yöntemlerinden tarama modelinde bir çalışmadır. Araştırmada amaçlı örnekleme türlerinden tipik durum örnekleme yöntemi tercih edilmiştir. Katılımcıların \% 60.7'si kız öğrenci iken, \% 39.3'ü ise erkek öğrencilerden oluşmaktadır. Araştırmaya katılan 145 öğrencinin 76'sı 5.sınıf, 33'ü 6.sınıf ve 36'sı ise 7.sınıf öğrencisidir. Araştırma da elde edilen veriler SPSS 22 programında analiz edilmiștir. Araştırmada elde edilen bulgulara göre, öğrencilerin \% 66.9'u görsel, \% 4.1 ' $\mathrm{i}$ hareket ve \% 29'u ise işitsel temelli öğrenme stiline sahiptir. Araştırma sonucunda öğrencilerin sosyal bilgiler dönem sonu notu ortalamaları ile görsel, hareket ve işitsel temelli öğrenme stilleri arasında anlamlı bir ilişki yoktur. Öğrenme stilleri ile cinsiyet arasında anlamlı bir farklılık yoktur. Fakat öğrenme stilleri ile sınıf düzeyleri arasında anlamlı bir farklılık görülmektedir. Hareket temelli ve görsel temelli öğrenme stilleri sınıf düzeylerine göre değişmezken, işitsel temelli öğrenme stilleri sınıf düzeylerine göre değişmektedir. Ölçekten elde edilen puanlara göre altıncı ve yedinci sınıftaki öğrencilerin işitsel temelli öğrenme stil düzeyleri beşinci sınıflara göre anlamlı derecede yüksektir.

Anahtar Kelimeler: Sosyal Bilgiler, Öğrenme Stili, Akademik Başarı, Cinsiyet, Sınıf Düzeyi

\section{Giriş}

Günümüzde eğitim alanındaki modern araştırmalar ve eğitimdeki yeni anlayışlar eğitim ve birey açısından büyük değişimleri kaçınılmaz kılmıştır (Kolb, 1985; 66). Aynı sınıf ortamında eşit deneyimlere sahip olduğu varsayılan öğrencilerin bilgi edinme ve öğrenme yöntemlerinin birbirinden farklı olduğu saptanmıştır. Öğrenme stilleri aktif yaşant1, somut yaşantı, soyut kavramları özümseme ve yansıtıcı gözlem temeline dayanır. Öğrenme stillerinin belirlenmesinde bireylerin öğrenme biçimlerinden elde edilen ortalama puanlarına onların hangi öğrenme stiline sahip olduklarını gösterir. Belirtilenler doğrultusunda her bireyin bilgiyi alma noktasında kendine özgü ayırt edici özellikleri bulunur. Bireylerin kendine özgü öğrenme stili, kişinin kalıtsal özellikleri, var olan ve geçmiş yaşantılarının ortak bir paydasıdır. Bundan dolayı döngüsel öğrenme ortamında bilgiyi alma, kavrama ve özümseme bireysel olarak farklı düzeylerde ve sürelerde gerçekleşir. Örneğin; bazı öğrenciler görsel materyallerden bazı öğrenciler dinleyerek daha iyi öğrenirken bazı öğrenciler ise yaparak yaşayarak daha iyi öğrenebilmektedir. $\mathrm{Bu}$ nedenle eğitimin planlama ve uygulama aşamasında bu bireysel farklılıklar göz önünde bulundurulmalıdır. Öğretmen dersi işlerken zengin bir öğretim ortamı oluşturmalıdır. Sınıftaki öğrencilerin öğrenme stillerini ve eğilimlerini göz önünde bulundurmalıdır. Bireysel farklılıkları göz ardı edilen öğrencilerin aynı öğrenme ortamında aynı tarz öğrenme modelleriyle öğrenmeye zorlanması eğitim sisteminin en büyük yanlışlarında biri olacaktır.

Her öğrenci farklı psikolojik, nörobiyolojik, gelişimsel özelliklerden etkilenen kendi özelinde bireylerdir. Bu anlayış yeni öğretim modellerinde kabul edilen bir gerçektir. Her çocuğun hatta yetişkinin düşünme ve öğrenmede kullandıkları yöntemler farklıdır (Litsinger ve Osif, 1993). 
Okul ortamı aynı olsa dahi öğrenenlerin farklı öğrenme stilleri olduğundan sınıf ortamında algılama, etkileşim kurma ve tepki verme şekilleri de farklıdır. Bu yönüyle öğretmenlerin sınıf içi ders planlarında öğrencilerin ihtiyaç ve ilgilerini bireysel farklılıklara uygun biçimde gözetmeleri gerekmektedir (Kaplan, 1995).

Öğrenme stillerinin birçok farklı boyutu vardır. Bunlar; bilgiyi işleme tarzı, psikolojik faktörler ve algısal tercihler ve alışkanlıklar olarak tanımlanabilir (Şimşek, 2002). Öğrenme stili bireylerin yaşadığı çevreyi algılama, öğrendiği bilgiyi işleme ve çevresiyle etkileşimde bulunmasında kullandığı tercihleri belirleyen bireysel niteliklerin toplamıdır (Şimşek,2002).Son yıllarda öğrenme stilleri ile ilgili yapılan birçok araştırmada öğrencilerin ders başarısını etkileyen birçok içsel ve çevresel unsurun olduğu ortaya çıkmıştır (Bilgin ve Durmuş, 2003). Bundan dolayı öğrencilerin okul başarısı ile öğrenme stilleri arasındaki bağlantıların araştırıldığı çalışmaların birçok dersle ilgili öğrenci grubunun öğrenme ortamına ve öğretim planlamalarına yönelik hazırlıklarında faydalı bilgiler sağlayabileceği öngörülmektedir.

Öğrenme stillerinin çeşitli yaş gruplarına uygulanmasında ve öğrenme farklılıklarının belirlenmesinde birçok değişik model ve ölçeklerden faydalanılmaktadır. Bu modeller içerisinde en sık kullanılan üç öğrenme stili yaklaşımlarından bahsedilebilir.

Bunlardan birincisi Amerika Birleşik Devletleri (ABD)'nde ortaya çıkan ve bireyin kendini tanıması ve öğrenme ortam ve yöntemini bireyselleştirdiği "Kişisel farkında olma" görüşüdür. "Kişisel farkında olma" görüşü birçok eğitimci tarafından kabul görmektedir. Bunlar arasında ünlü eğitim bilimci Gregorc gelir. Gregorc (1974)'a göre her birey kendine özeldir. Kişinin öğrenmesinde ve öğrenme stillerinde algılama yeteneği çok önemlidir. Kişiler algılama yeteneklerine göre somut ve soyut algılayanlar, algıladıkları verileri düzenleme yeteneklerine göre sıralı ve rastgele olmak üzere ikiye ayrılırlar. Kişilerin algılama yeteneklerine göre de oluşturdukları öğrenme durumları onların öğrenme stillerini oluşturur (Gregorc, 1979). Eğitim ortamlarının bireyselleştirilmesi ve eğitimin bireysel planlamalarla tekrar düzenlemesi gerektiğini ifade eder. Aslında eğitimin bireyselleştirilmesi görüşü hemen hemen bütün eğitim bilimcilerin hem fikir olduğu bir konudur. Fakat nüfusu genç ve kalabalık olan Türkiye gibi ülkelerde eğitimin bireyselleştirlmesi imkân ve olanaklarının kısıtlı olduğu görülmektedir. Fakat okulların nitelik durumları göz önünde bulundurularak bireyselleştirilmiş destek eğitimlerin verilmesi mümkün görünmektedir.

İkinci yaklaşımda ise her bireyin tanısal olarak öğrenmeye yatkınlık düzeyi saptanır. $\mathrm{Bu}$ saptama yapılırken bireyin bilişsel, duyuşsal ve psikomotor gelişimleri göz önünde bulundurularak öğrenme ortamı ve planlaması hazırlanır. Öğrencinin özelliğine uygun materyaller geliştirilir. $\mathrm{Bu}$ yaklaşımı benimseyen eğitimcilerin başında Dunn ve Carbo gösterilebilir (Dunn, R. ve Carbo, M. 1981; 381-382). Bir diğer yaklaşım da bireysel öğrenme modeli (Keller planı) ile program tasarımı ve öğrenme sürecine uygulama yaklaşımıdır. Her bireyin farklı yöntemlerle öğrendiği ve eğitim planlamasının bireysel olması gerektiğini kabul eden yaklaşımdır.

Bu yaklaşımı benimseyenler arasında 'Deneysel Öğrenme', adlı kitabın yazarı Kolb (1985) gelmektedir. Bireyin öğrenme stilini teşhis ederek bireye özgü bir öğrenme planı hazırlamayı ilke edinen bu yaklaşımda bireysel öğrenme stili envanteri hazırlayarak bireyin kendini tanımasına imkân sağlanır. Kolb, 'Deneysel Öğrenme"' adlı kitabında bireylerin öğrenme sürecinde bilgiyi alma, özümseme ve işleme konularında bireyselleştirmenin ön planda olduğunu vurgulamıştır. Kolb'a göre öğrenme stilleri aktif yaşantı, somut yaşantı, soyut kavramları özümseme ve yansitıcı gözlem temeline dayanır. Öğrenme stillerinin belirlenmesinde bireylerin öğrenme biçimlerinden elde edilen ortalama puanlarına onların hangi öğrenme stiline sahip olduklarını gösterir. Belirtilenler doğrultusunda her bireyin bilgiyi alma noktasında kendine özgü ayırt edici özellikleri bulunur. Bireylerin kendine özgü öğrenme stili, kişinin kalıtsal özellikleri, var olan ve geçmiş yaşantılarının ortak bir paydasıdır. Bundan dolayı döngüsel öğrenme ortamında bilgiyi alma, kavrama ve özümseme bireysel olarak farklı düzeylerde ve sürelerde gerçekleşir. 
$\mathrm{Bu}$ yönüyle öğrenme döngüsel öğrenme ortamında farklı düzeydeki öğrencilerin kendine özgü öğrenme biçemlerinin olduğu kabul gören bir anlayıştır. Kolb (1985), öğrenme stilinin sürekli değişen, dinamik ve kişiye özgü olduğunu vurgulamıştır. Bireylerin öğrenme stilleri belirlenirken bireylerin somut yaşantılarının soyut kavramları aktif yaşantı sürecinde ne derecede ayrıştırdığı, özümsediği, zihnine yerleştirdiği ve değiştirip kullanabildiği ölçüdeki gözlemlerinin sonucu olduğu temeline dayanır. $\mathrm{Bu}$ temel doğrultusunda Kolb'un öğrenme modeli aşağıda şema halinde gösterilmiştir.

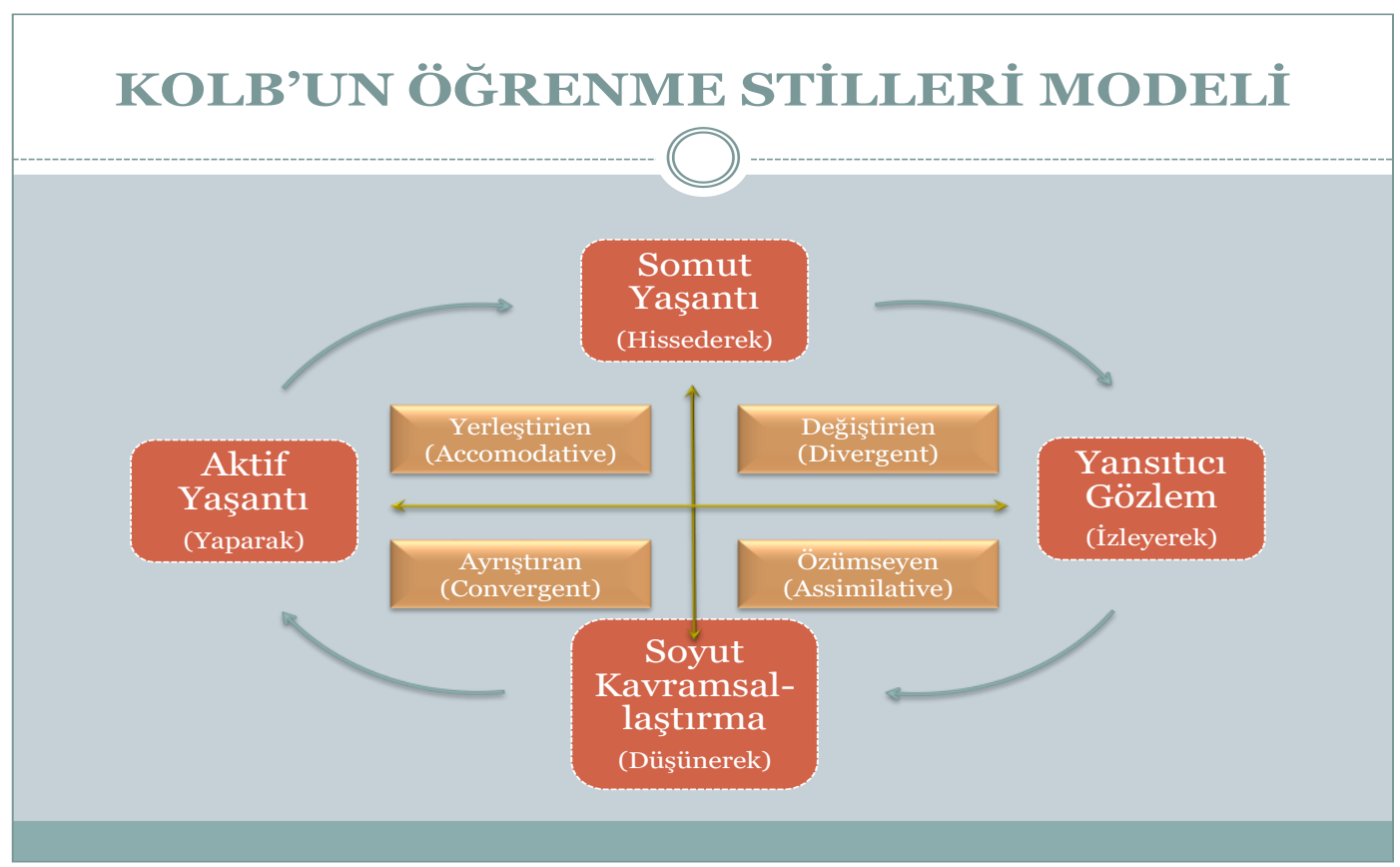

Şekil 1: Kolb’un Öğrenme Modeli (Kolb, 1985).

Kolb (1985) belirlediği öğrenme stillerinin belirlenmesinde kullanılan öğrenme modelinde kullandığı dört öğrenme biçiminin sonucunda belirlenmiştir. Aktif yaşantı ile yansitıcı gözlem boyutlarını bireyin somut yaşantılar sonucu elde ettiği deneyimler soyut kavramları özümseme noktasında başarı düzeyini belirlemiştir (Hayes ve Allinson, 1994: 53-71).

Kolb'un öğrenme modelinde belirttiği öğrenme biçimlerinin sonucunda ortaya çıkarılan öğrenme stilleri şunlardır:

Özümseyen öğrenme stili: Bireylerin bilgiyi işleme sürecinde yansıtıcı gözlemleri kullanarak soyut kavramları özümlemesi ve zihninde belli bir şemaya oturtmasıdır. Özümseyen öğrenme stiline sahip bireyler soyut kavramları ve fikirleri öğrenirken başarılıdırlar. Kavramsal modeller tasarlayabilir (Akkoyunlu ve Aşkar, 1993). Ayrıca bu öğrenme stiline göre öğrenen bireylerde matematiksel ve mantıksal ifadeler öğrenme bilgiyi değişik biçimlerde uygulama konusunda başarılıdırlar. Üç boyutlu nesneleri zihninde canlandırabilir, soyut kavramları özümseyerek farklı durumlarda uygulayabilirler (Kolb, 2005).

Değiştiren öğrenme stili: Bireylerin bilgiyi işleme sürecinde somut yaşantıları ön plandadır. Yansıtıcı gözlem öğrenme biçimlerini aktif olarak kullanırlar. Birçok yönden somut olayları gözden geçirerek öğrenmeye çalışırlar. Değiştiren öğrenme stiline uygun öğrenmeye yatkın bireyler öğrenirken sabırlıdırlar. Olaylar karşısında nesnel ve objektiftirler. Dikkatli değerlendirmelerde bulunurlar. Fakat çoğu zaman eylemde bulunmazlar (Akkoyunlu ve Aşkar, 1993). Bilgiyi toplamaktan çekinmeyen geniş kültürel ilgilere sahip olan bu bireyler çevreleriyle barışık ve 
duyarlıdırlar. İnsanlarla vakit geçirmekten haz alan yaratıcı ve duygusal eğilimleri ön planda olan kişilerdir. Sanata ve edebiyata ilgi duyarlar. Ayrıca yüz yüze eğitim ortamlarında grupla yapılan çalışmaları seven açık fikirli ve iyi bir dinleyicidirler (Kolb, 2005).

Ayrıştıran öğrenme stili: Bireylerin aktif yaşantıları sayesinde aldıkları bilgiyi soyut kavramsallaştırma aracılığıyla işlerler. Bu öğrenme stilin sahip bireyler teorik bilgiyi pratiğe çevirmede ve sorunlara çözümler üretme konusunda çevrelerine göre daha ön plandadırlar. Sosyal ve bireylerarası problemlerden çok teknik konular ve sorunlarla ilgilenmeye daha isteklidirler. $\mathrm{Bu}$ öğrenme stilini beceri haline getiren bireyler teknoloji ve bilimsel bilgi uzmanlığı alanlarında kariyer yapmaya meyillidirler. Yüz yüze eğitim ortamlarında, analiz yapan yeni düşüncelere açık simülasyonlara meraklı ve laboratuar ortamlarında zaman geçirmeyi seven pratik çalışmaya dönük bireylerdir (Kolb, 2005).

Yerleştiren öğrenme stili: öğrenme biçimi olarak aktif ve somut yaşantıların merkezinde bulunur. Bu öğrenme stili ile öğrenen bireyler hayatının tüm zamanını planlar ve planlama yaparak işlerini tasarlarlar. Aldıkları kararları uygulamada yeni tecrübeler içinde yer almak başlıca özelliklerindendir. Öğrenme esnasında yeni görüşlere saygılı açık fikirli ve değişime ayak uydurabilen yapıları vardır (Kolb, 1985). Yerleştiren öğrenme stilinde yaparak ve yaşayarak öğrenme ön plandadır. Bu stilde öğrenmeye eğilimli bireylerin aktif öğrenme becerileri çevrelerine göre hissedilebilir derecede fazladır. Tasarılarını hayata geçirmeye ve yeni maceralara ve deneyimlere girişmekten çekinmeyen yapıları vardır. Bu tarz öğrenen bireyler kendilerinin çözüm ve teknik analizlerini de göz önünde bulundurup her şeyi tartışarak ve sosyal uyum içerisinde ortak paydada buluşmayı seven kişilerdir. Yüz yüze eğitim ortamlarında yerleştiren öğrenme stili ile öğrenmeye yatkın bireyler herhangi bir grup çalışması içerisinde farklı yaklaşım ve teknikleri denemekten kaçınmayan amaç ve plan yaparak ortak hareket eden uyumlu bireylerdir (Kolb, 2005).

$\mathrm{Bu}$ doğrultuda Sosyal bilgiler dersinde öğrenme stillerinin akademik başarıyla ilişkisinin olup olmadığının ortaya konması literatüre katkı sağlayacaktır. Öğrenme ve öğretme sürecinin planlanıp düzenlenmesi esnasında öğrencilerin kendine özgü öğrenme stillerinin dikkate alınıp uygulanmasının akademik başarıyı arttıracağı düşünülmektedir.

$\mathrm{Bu}$ araştırmada ortaokul öğrencilerin sosyal bilgiler dersinde akademik başarı ortalamalarının öğrenme stilleriyle ilişkisi ve öğrenme stilinin cinsiyet ve sınıf düzeylerine göre değişip değişmediğinin araştırılması hedeflenmiştir. Bu bağlamda araştırmada aşağıda yer alan sorulara cevap aranmıştır:

1.Katılımcıların hareket, işitsel ve görsel öğrenme stilleri nasıl bir dağılım göstermektedir? midir?

2.Öğrenme stilleri ile sosyal bilgiler dersi akademik başarıları arasında anlamlı bir ilişki var

3.Öğrenme stilleri cinsiyet durumlarına göreanlamlı farklılık göstermekte midir?

4.Öğrenme stilleri sınıf düzeylerine göre anlamlıbir farklılık göstermekte midir?

\section{Yöntem}

Nicel araştırma deseninde olan bu çalışma da tarama modeli kullanılmıştır. Karasar'a (2016, s. 109) göre tarama modeli "geçmişte ya da halen var olan bir durumu var olduğu şekliyle tespit etmeyi amaçlayan araştırma modelidir."

\section{Örneklem}

Bu çalışma 2019- 2020 eğitim öğretim yılı birinci döneminde Diyarbakır ilinde yer alan iki ortaokulda gerçekleştirilmiştir. Araştırmada amaçlı örneklemetürlerinden tipik durum örnekleme yöntemi kullanılmıştır. Bu örnekleme yönteminde amaç araştırma probleminin evrendeki çok sayıda örneğini tipik olarak yansıtan grupların seçilmesidir (Büyüköztürk vd. 2014). Araştırmaya 88 kız 
öğrenci ve 57 erkek öğrenci katılmıştır. Grafik 1'de araştırmaya katılan öğrencilerin dağılımları gösterilmektedir.

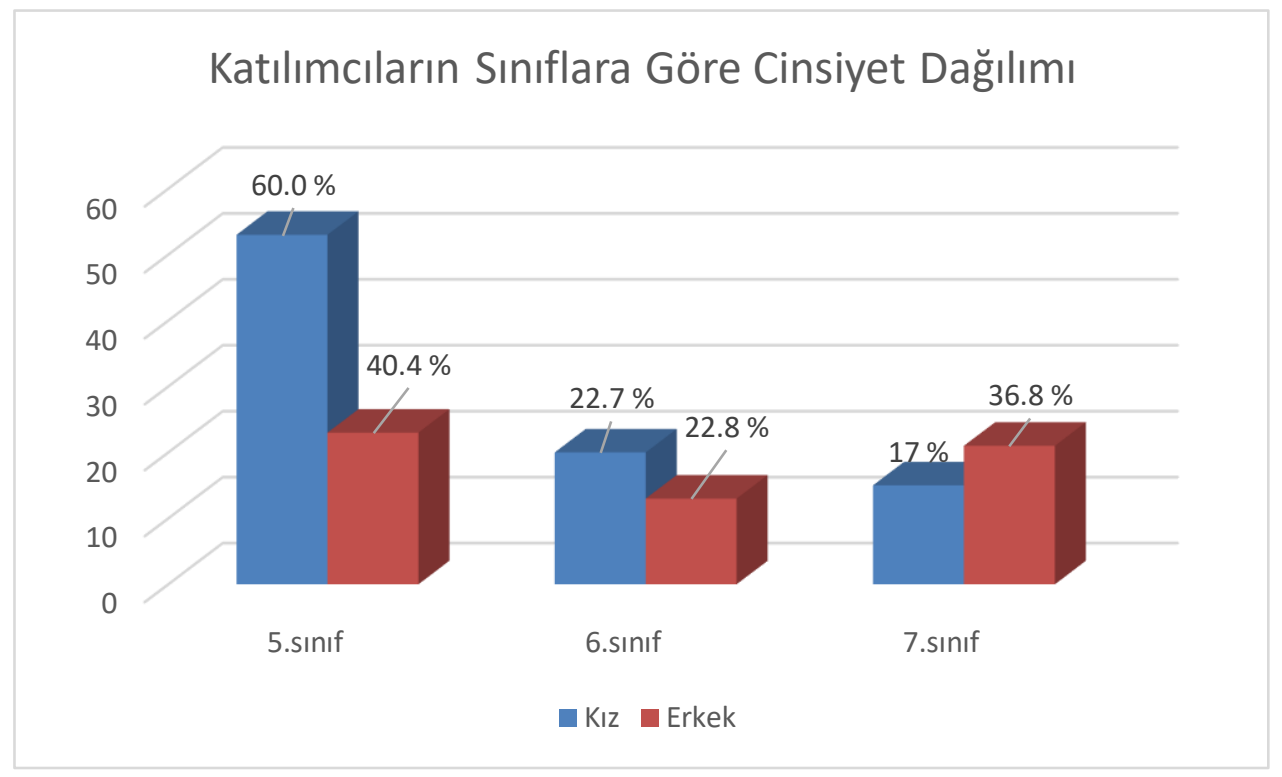

Grafik 1: Sınıflara göre cinsiyet dağılımları

Katılımcıların \% 60.7'si kız öğrenci iken, \% 39.3'ü ise erkek öğrencilerden oluşmaktadır. Araştırmaya katılan 145 öğrencinin 76's1 5.sınıf, 33'ü 6.sınıf ve 36's1 ise 7.sınıf öğrencisidir. Öncelikle öğrenciler araştırma hakkında bilgilendirilmiş ve gönüllülük esasına dayalı olarak eğitim öğretim faaliyetlerini aksatmayacak bir şekilde veri toplama aracı öğrenci tarafından doldurulmuştur. Araştırmada etik ilke ve kaidelere dikkat edilmiştir.

\section{Veri Toplama Aracı}

Araştırmada öğrenci bilgi formu ve Sever (2008) tarafından geliştirilen öğrenme stilleri ölçeği kullanılmıştır. Bu ölçeğin bu araştırmada kullanılmasının sebebi ölçeğin sınıf düzeylerine uygun olmasıdır. Altıncı, yedinci ve sekizinci sınıflar için geliştirilen ve 17 maddeden oluşan bu ölçek 3 faktörlü olup toplam varyansın \% 40.15'ini açıklamaktadır. Ölçeğin Cronbach Alfa iç tutarlılık katsayısı her bir alt boyut için .67 olarak hesaplanmıştır. Bu çalışma da ise ölçeğin görsel temelli öğrenme stili Cronbach Alfa iç tutarlılık katsayısı .63, hareket temelli öğrenme stili Cronbach Alfa katsayısı .69 ve işitsel temelli ögrenme stili Cronbach Alfa iç tutarlılık katsayısı ise .65'tir.

\section{Verilerin Analizi}

Araştırmanın verileri SPSS 22 programı marifetiyle analiz edilmiştir. Öğrencilerin sosyal bilgiler dersi dönem sonu ortalamaları ile öğrenme stilleri arasında anlamlı bir ilişki olup olmadığını test etmek amacıyla basit doğrusal korelasyon testi yapılmıştır. Öğrencilerin öğrenme stilleri ile cinsiyet durumları arasında anlamlı bir farklılık olup olmadığını test etmek için öncelikle normallik değerlerinden çarpıklık ve basıklık değerlerine bakılmıştır. Veriler normal dağıldığı için ilişkisiz örneklemler için $\mathrm{t}$ testi uygulanmasına karar verilmiştir. Öğrencilerin sınıf düzeyi ile öğrenme stilleri arasında anlamlı bir farklılık olup olmadığına bakmak için öncelikle sınıf değişkenine göre puan dağılımlarının normallik değerlerine bakılmıştır. Verilerin çarpıklık ve basıklık değerlerine göre normal dağıldığı görülmektedir. Bununla birlikte varyanların homojen olup olmadığına karar vermek için de Levene testi sonucuna bakılmıştır. Levene testi sonucuna göre $(p>0.005)$ grupların 
varyanslarının eşit olduğu görülmektedir. Bu nedenle sınıf düzeyleri ile öğrenme stilleri arasında anlamlı bir farklılık olup olmadığını test etmek için tek yönlü varyans analizi testi (ANOVA) uygulanmıştır. Anlamlı farkın hangi gruplar arasında olduğunu test etmek için çoklu karşılaştırma testlerinden LSD testi yapılmıştır. Çünkü LSD testi, varyansların homojenliği koşulunun sağlandığı durumlarda ve örneklemlerin eşit olmadığı durumlarda kullanılabilecek testlerden biridir (Kayri, 2009, s.56). Aşağıda yer alan Tablo 1'de cinsiyet ve sınıf değişkenlerinin çarpıklık ve basıklık değerleri verilmiştir.

Tablo1: Cinsiyet ve sınıf değişkenlerine ait çarpıklık ve basıklık değerleri

\begin{tabular}{lllllll}
\hline & \multicolumn{2}{l}{ İsitme Temelli } & \multicolumn{2}{l}{ Hareket Temelli } & \multicolumn{2}{l}{ Görsel Temelli } \\
\hline Cinsiyet & $\begin{array}{l}\text { Çarpıklık } \\
\text { (Skewness) }\end{array}$ & $\begin{array}{l}\text { Basıkık } \\
\text { (Kurtosis) }\end{array}$ & $\begin{array}{l}\text { Çarpıklık } \\
\text { (Skewness) }\end{array}$ & $\begin{array}{l}\text { Basıklık } \\
\text { (Kurtosis) }\end{array}$ & $\begin{array}{l}\text { Çarpıklık } \\
\text { (Skewness) }\end{array}$ & $\begin{array}{l}\text { Basıklık } \\
\text { (Kurtosis) }\end{array}$ \\
\hline Kız &,- 474 &,- 748 & 1,155 &, 797 &,- 634 &,- 026 \\
Erkek &, 025 &,- 073 &, 624 &,- 511 &,- 526 &, 023 \\
\hline Sınıf & Çarpıklık & Basıklık & Çarpıklık & Basıklık & Çarpıklık & Basıklık \\
& (Skewness) & (Kurtosis) & (Skewness) & (Kurtosis) & (Skewness) & (Kurtosis) \\
\hline 5.sınıf &,- 066 &,- 690 & 1,088 &, 745 &,- 759 &,- 095 \\
6.sınıf &,- 434 &, 178 &, 439 &,- 495 &,- 206 &, 598 \\
7.sınıf &,- 569 &,- 433 &, 942 &,- 365 &,- 880 &, 596 \\
\hline
\end{tabular}

Tablo 1'e göre çarpıklık ve basıklık değerleri -2 ve +2 arasında değişmektedir. George ve Mallerry'e (2003) görebu değerle -2 ve +2 arasında ise verilerin dağılımı normaldir.

\section{Bulgular}

Bu bölümde araştırmaya ilişkin bulgular yer almaktadır.

\section{Araştırma Sorusuna Yönelik Bulgular}

Araştırmaya katılan öğrencilerin ölçekten almış oldukları puan ortalamalarına göre hangi öğrenme stiline sahip olduklarına ilişkin dağılım Tablo 2' de yer almaktadır.

Tablo 2: Katılımcıların öğrenme stilleri

\begin{tabular}{lcc}
\hline \multicolumn{1}{c}{ Öğrenme Stili } & Frekans (f) & Yüzde (\%) \\
\hline Görsel Temelli Öğrenme Stili & 97 & 66.9 \\
Hareket Temelli Öğrenme Stili & 6 & 4.1 \\
İşitsel Temelli Öğrenme Stili & 42 & 29 \\
\hline
\end{tabular}

Araştırmaya katılan öğrencilerin \% 66.9'u görsel, \% 4.1'i hareket ve \% 29'u ise işitsel temelli öğrenme stiline sahiptir. Bu sonuçlara göre öğrencilerin ekseriyetle görsel öğrenme stiline sahip olduğu görülmektedir.

\section{Araştırma Sorusuna Yönelik Bulgular}

Ortaokul öğrencilerinin sosyal bilgiler dersi dönem sonu notu ile öğrenme stillerinin her bir boyutu arasındaki ilişkiyi gösteren basit doğrusal korelasyon sonucu Tablo 3'te gösterilmiştir.

Tablo 3: Sosyal bilgiler not ortalaması ile öğrenme stili arasındaki ilişki

\begin{tabular}{lcc}
\hline \multicolumn{1}{c}{ İlişki } & Pearson'sCorrelations & p \\
\hline Y1l sonu notu ve görsel temelli öğrenme stili & 0.009 & $<.001$ \\
Y1l sonu notu ile hareket temelli öğrenme stili & 0.116 & $<.001$ \\
Y1l sonu notu ile işitsel temelli öğrenme stili & 0.013 & $<.001$ \\
\hline
\end{tabular}


Tablo 3'de öğrencilerinin sosyal bilgiler dönem sonu notu ortalamaları ile öğrenme stillerinin her bir alt boyutu arasında anlamlı bir ilişki olup olmadığını test etmek amacıyla yapılan Pearson basit doğrusal korelasyon testi sonucunda, öğrencilerin sosyal bilgiler dönem sonu notu ortalamaları ile görsel, hareket ve işitsel temelli öğrenme stilleri arasında anlamlı bir ilişki yoktur.

Anlamlı bir ilişki olmasa da her bir öğrenme stili ile dönem sonu başarı notu ortalamaları arasında pozitif yönde bir ilişkinin olduğu görülmektedir. Hareket temelli öğrenme stilinin dönem sonu notu üzerinde diğer öğrenme stillerine göre daha yüksek bir ilişkinin olduğu görülmektedir.

\section{Araştırma Sorusuna Yönelik Bulgular}

Öğrencilerin öğrenme stillerinin cinsiyet durumuna göre değişip değişmediğini test etmek amacıyla ilişkisiz örneklemler için t testi yapılmıştır. Tablo 4'de öğrencilerin ortalamaları Tablo 5'te ise $t$ testi sonuçları verilmiştir.

Tablo 4: Cinsiyet durumuna göre öğrenme stili ortalamaları

\begin{tabular}{lllll}
\hline Öğrenme stili & Cinsiyet & $\mathbf{N}$ & Ortalama $\overline{\mathbf{X}}$ & $\begin{array}{l}\text { Standart } \\
\text { Sapma }\end{array}$ \\
\hline Hareket & Kız & 88 & 9,1477 & 2,93038 \\
& Erkek & 57 & 9,6140 & 2,60326 \\
\hline İsitsel & Kız & 88 & 8,8295 & 2,34507 \\
& Erkek & 57 & 8,5088 & 1,76395 \\
\hline Görsel & Kiz & 88 & 18,0114 & 2,18929 \\
& Erkek & 57 & 17,6842 & 1,93795 \\
\hline
\end{tabular}

Tablo 5: Cinsiyet durumuna göre $\mathrm{t}$ testi sonuçları

\begin{tabular}{llll}
\hline Ölçek & t & df & p \\
\hline Hareket temelli öğrenme stili & 0.977 & 143 & 0.330 \\
\hline İşitsel temelli öğrenme stili & 0.937 & 143 & 0.350 \\
\hline Görsel temelli öğrenme stili & 0.919 & 143 & 0.360 \\
\hline
\end{tabular}

Öğrencilerin öğrenme stillerinin cinsiyet durumuna göre değişip değişmediğini test etmek amacıyla yapılan ilişkisiz örneklemler için $\mathrm{t}$ testi sonucuna göre, kız ve erkek öğrencilerinhareket temelli, işitsel temelli ve görsel temelli öğrenme stilleri arsında istatistiki olarak anlamlı bir farklılı̆̆ın olmadığı görülmektedir.

\section{Araştırma Sorusuna Yönelik Bulgular}

Araştırmaya katılan öğrencilerin öğrenme stillerinin sınıf düzeyine göre değişip değişmediğini test etmek amacıyla yapılan ANOVA yapılmıştır. Aşağıda yer alan Tablo 6'da öğrencilerin sınıf düzeyine göre ortalamaları Tablo 7'de ise ANOVA sonuçları verilmiştir.

Tablo 6: Sınıf düzeylerine göre öğrenme stili ortalamaları

\begin{tabular}{|c|c|c|c|c|c|c|}
\hline \multirow[t]{2}{*}{ Sinif } & \multicolumn{2}{|c|}{ İşitsel temelli } & \multicolumn{2}{|c|}{ Hareket temelli } & \multicolumn{2}{|c|}{ Görsel temelli } \\
\hline & $\overline{\boldsymbol{X}}$ & $S d$ & $\overline{\bar{X}}$ & $S d$ & $\overline{\boldsymbol{X}}$ & $S d$ \\
\hline 5.sinif & 2,0362 & 2,207 & 1,5373 & 2,92 & 2,5959 & 2,32 \\
\hline 6.sinif & 2,3258 & 1,911 & 1,5455 & 2,41 & 2,4632 & 1,50 \\
\hline 7.sinif & 2,3333 & 1.882 & 1,6019 & 2,94 & 2,5516 & 1,94 \\
\hline
\end{tabular}


Tablo 7: Sınıflara göre ANOVA sonuçları

\begin{tabular}{|c|c|c|c|c|c|}
\hline \multicolumn{6}{|c|}{ Hareket temelli ögrenme stili } \\
\hline Varyansın Kaynağı & Kareler Toplamı & Df & $\begin{array}{l}\text { Kareler } \\
\text { Ortalaması }\end{array}$ & $\mathbf{F}$ & $\mathbf{p}$ \\
\hline Gruplar arası & 3.812 & 2 & 1,906 & 0.239 & 0.787 \\
\hline Gruplar içi & 1130.298 & 142 & 7,960 & & \\
\hline \multicolumn{6}{|c|}{ İşitsel temelli ögrenme stili } \\
\hline \multicolumn{6}{|l|}{$\begin{array}{l}\text { Varyansın } \\
\text { Kaynağı }\end{array}$} \\
\hline Gruplar arası & 49.871 & 2 & 24.935 & 5.839 & 0.004 \\
\hline Gruplar içi & 606.378 & 142 & 4.270 & & \\
\hline \multicolumn{6}{|c|}{ Görsel temelli öğrenme stili } \\
\hline \multicolumn{6}{|l|}{$\begin{array}{l}\text { Varyansın } \\
\text { Kaynağı }\end{array}$} \\
\hline Gruplar arası & 19.864 & 2 & 9.932 & 2.308 & 0.103 \\
\hline Gruplar içi & 611.142 & 142 & 4.304 & & \\
\hline
\end{tabular}

Araştırmaya katılan öğrencilerin öğrenme stillerinin sınıf düzeylerine göre değişip değişmediğini test etmek amacıyla yapılan ANOVA sonucunda hareket temelli ve görsel temelli öğrence stilleri sınıf düzeylerine göre anlamlı olarak değişmezken; işitsel temelli öğrenme stilleri sınıf düzeylerine göre istatistiki olarak farklılaşmaktadır. Test sonucu etki büyüklüğü $(\eta 2=0,075)$ olarak hesaplanmıştır. Elde edilen etki büyüklüğünün orta düzeyde olduğu görülmektedir (Green ve Salkind, 2005, s.157). Yapılan LSD çoklu karşılaştırma testi sonucunda, anlamlı farkın, 5.sınıf ile 6.ve 7.sinıflar arasında olduğu görülmektedir.

\section{Sonuç, Tartışma ve Öneriler}

$\mathrm{Bu}$ araştırmada beşinci, altıncı ve yedinci sınıf sosyal bilgiler dersinde öğrencilerin akademik başarıları ile öğrenme stilleri arasında anlamlı bir ilişki olup olmadığı test edilmiştir. Bu araştırmada, öğrencilerin sosyal bilgiler dersi akademik başarıları ile öğrenme stilleri arasında pozitif yönde bir ilişkinin olduğu görülmektedir. Fakat bu ilişkinin istatistiki olarak anlamlı olmadığı görülmektedir. Literatürde bu sonuçla örtüşmeyen çalışmaların olduğu görülmektedir. Kazu ve Akran (2018) 5. ve 6.sınıf öğrencileriyle gerçekleştirmiş olduğu araştırmada öğrenme stilleri ile akademik başarı arasında anlamlı bir ilişkinin olduğunu tespit etmiştir. Bakır ve Mete (2014) de ortaokul öğrencileriyle yapmış olduğu araştırmada Fen ve Teknoloji dersiyle öğrenme stilleri arasında anlamlı bir ilişkinin olduğunu tespit etmiştir. Bu sonuçlardan hareketle öğrenme stili ile akademik başarı arasındaki ilişkinin derslere göre farklılık gösterebileceği şeklinde yorumlanabilir.

Öğrenme stillerinin cinsiyet durumuna göre değişip değişmediğini test etmek amaciyla yapılan ilişkisiz örneklemler için t testi sonucuna göre, kız ve erkek öğrencilerin hareket temelli, işitsel temelli ve görsel temelli öğrenme stilleri arasında istatistiki olarak anlamlı bir farklılığın olmadığ1 görülmektedir. Literatürde bu sonuçla örtüşen ve örtüşmeyen bulgular olduğu görülmektedir. Bakır ve Mete (2014) ortaokul öğrencileriyle yapmış olduğu araştırmada cinsiyet ile öğrenme stilleri arasında farklılıklar olduğunu ifade ederken; Ok (2009), Arslan ve Babadoğan (2005) yedinci ve sekizinci sınıflar üzerinde yapmış oldukları araştırmalarda öğrenme stilleri ile cinsiyet arasında anlamlı bir farklılık bulmamışlardır. 
Öğrenme stillerinin sınıf düzeylerine göre değişip değişmediğini test etmek amacıyla yapılan ANOVA sonucunda, hareket temelli ve görsel temelli öğrenme stilleri sınıf düzeylerine göre değişmezken, işitsel temelli öğrenme stilleri sınıf düzeylerine göre değişmektedir. Ölçekten elde edilen puanlara göre altıncı ve yedinci sınıftaki öğrencilerin işitsel temelli öğrenme stil düzeyleri beşinci sınıflara göre anlamlı derecede yüksektir. Altıncı ve yedinci sınıf öğrencilerinin işitsel temelli öğrenme stillerinin beşinci sınıflara göre daha baskın olması bu sınıfa devam eden öğrencilerin soyut zekalarının daha gelişmiş olmasından kaynaklanabilir. İstatistiksel olarak anlamlı olmasa da beşinci sınıf öğrencilerin görsel temelli öğrenme stil düzeylerinin altıncı ve yedinci sınıftaki öğrencilerden yüksek olduğu görülmektedir. Beşinci sınıf öğrencilerin görsel temelli öğrenme stillerinin altıncı ve yedinci sınıflara göre daha baskın olmasının sebebi yaşa bağlı zihinsel gelişimsel özelliklerden kaynaklanıyor olabilir. Bakır ve Mete (2014) de ortaokul öğrencileriyle yapmış olduğu araştırmada sinıf düzeyleri ile öğrenme stilleri arasında manidar bir fark bulurken; Ok (2009) yedinci ve sekizinci sınıflar ile yapmış olduğu araştırmada öğrenme stilleri ile sınıf düzeyleri arasında manidar bir farklılık bulmamıştır. Öğrenme stilinin cinsiyet ve sınıf düzeylerine göre farklılaşıp farklılaşmadığına yönelik yapılan araştırma sonuçları bu araştırmanın sonuçlarıyla karşılaştırıldığında bu araştırmayı destekleyen sonuçlar olduğu gibi, bu araştırmanın sonuçlarıyla örtüşmeyen sonuçların da olduğu görülmektedir.

$\mathrm{Bu}$ sonuçlardan hareketle araştırmacı ve uygulatıcılara bazı önerilerde bulunulmuştur.

Uygulayıcılara yönelik öneriler: koşmalıdır.

Sosyal bilgiler öğretmenleri sınıf düzeylerini göz önünde bulundurarak öğrenme stillerini işe

Araştırmacılara yönelik öneriler:

Literatürde genellikle öğrenme stillerine yönelik çalışmaların kesitsel çalışmalar olduğu görülmektedir. Öğrencilerin öğrenme stillerinin zamana göre değişip değişmediğini test etmek amacıyla boylamsal çalışmalar yapılabilir.

$\mathrm{Bu}$ araştırma, var olanı tespit etmeye yönelik tarama modelinde nicel bir çalışmadır. Öğrenme stilleri üzerinde etki edebilecek değişkenlerin neler olduğunu daha derinlemesine araştırmak için nitel veya karma desende çalışmalar da yapılabilir.

$\mathrm{Bu}$ çalışma Diyarbakır ilinde gerçekleştirilmiş olup benzer bir çalışma farklı bölge ve illerde gerçekleştirilebilir.

\section{Kaynakça}

Arslan, B. ve Babadoğan, C. (2005). İlköğretim 7. ve 8. Sinıf öğrencilerinin öğrenme stillerinin akademik başarı düzeyi, cinsiye ve yaş ile ilişkisi. Eurasian Journal of Educational Research, 21, 35-48.

Aşkar, P. ve Akkoyunlu, B. (1993). Kolb Öğrenme Stili Envanteri. Eğitim ve Bilim, (87) 37- 47.

Bakır, S. ve Mete, H. (2014). Ortaokul öğrencilerinin öğrenme stilleri: Burdur ili örneği. Kırşehir Ahi Evran Üniversitesi Eğitim Fakültesi Dergisi, 15 (3), 127-145. https://doi.org/10.19171/uefad.679322

Büyüköztürk, Ş., Çakmak, E. K., Akgün, Ö. E., Karadeniz, Ş. ve Demirel, F. (2014). Bilimsel Araştırma Yöntemleri. Pegem Akademi.

Gencel, E. İ. (2006). Öğrenme stilleri, deneyimsel öğrenme kuramına dayalı eğitim, tutum ve sosyalbilgiler program hedeflerine erişi düzeyi. (Yayınlanmamış Doktora Tezi). Dokuz Eylül Üniversitesi Eğitim Bilimleri Enstitüsü. 
George, D. ve Mallery, M. (2003). Spss for windows step by step: a simple guideandreference 11.0 update (4.bs.): Pearson.

Green, S. andSalkind, N. (2005). Using SPSS for Windows and Macintosh: UnderstandingandAnalysing Data. Upper Saddle River, NJ: PrenticeHall.

Gregorc, A. F. (1979). Learning/ teaching styles: Their nature and effects. In student learning styles: Diagnosing and prescribing program. Reston. VA: National Association of Secondary School Principals.

Hayes, J. ve C. Allinson (1994), "Cognitive style and its relevance for management practice”, British Journal of Management, Vol. 5, 53-71. https://doi.org/10.1111/j.1467-8551.1994.tb00068.x

Karasar, N. (2016). Bilimsel Araştırma Yöntemi. (30.baskı), Nobel yayınevi.

Kayri, M. (2009). Araştırmalarda Gruplar Arası Farkın Belirlenmesine Yönelik Çoklu Karşılaştırma (POST-HOC) Teknikleri. Firat Üniversitesi Sosyal Bilimler Dergisi, 19 (1), 51-64.

Kazu, İ. Y., ve Koç-Akran, S. (2018). 5. ve 6. sınıf öğrencilerininöğrenme stilleri ile akademik başarıları arasındaki ilişki (Malatya ve Elazığ ili örneği). CurrResEduc, 4(2), 62-85.

Kolb, A. ve Kolb, D. (2005). Learning Stylesand Learning Spaces: Enhancing Experiential Learning in HigherEducation. Academy of Management Learning \& Education, 4 (2), 193-212. https://doi.org/10.5465/amle.2005.17268566

Kolb, D. A. (1985). Kolb's Learning Style Inventory: reviewand further study of validityandreliability. British Journal of Educational Psychology. 66 (2) Blackwell Publishing Ltd.

Ok, E.G. (2009). İlköğretim öğrencilerinin ögrrenme biçimlerinin sinıf düzeyi, cinsiyet ve akademik başarı ile ilişkisi. (Yayınlanmamış yüksek lisans tezi). Uludağ Üniversitesi Sosyal Bilimler Enstitüsü.

Sever, E. (2007). Öğrenme stilleri: ilköğretim 6-8.sinıf öğrencilerine yönelik bir ölçek geliştirme çalışması. (Yayınlanmamış yüksek lisans tezi). Adnan Menderes Üniversitesi Sosyal Bilimler Enstitüsü. 